\title{
Frequency of glycogen storage disease type II in The Netherlands: implications for diagnosis and genetic counselling
}

\author{
MGEM Ausems $^{1}$, J Verbiest ${ }^{2,3}$, MMP Hermans $^{2,3}$, MA Kroos ${ }^{2}$, FA Beemer ${ }^{1}$, \\ JHJ Wokke ${ }^{4}$, LA Sandkuijl ${ }^{1,2}$, AJJ Reuser ${ }^{2}$ and AT van der Ploeg ${ }^{3}$ \\ ${ }^{1}$ Department of Medical Genetics, University Medical Center, Utrecht \\ ${ }^{2}$ Department of Clinical Genetics, Erasmus University, Academic Hospital, Rotterdam \\ ${ }^{3}$ Department of Pediatrics, Sophia Children's Hospital, Rotterdam \\ ${ }^{4}$ Department of Neurology, University Medical Center, Utrecht, The Netherlands
}

\begin{abstract}
Glycogen storage disease type II (GSD II) is an autosomal recessive myopathy. Early and lateonset phenotypes are distinguished - infantile, juvenile and adult. Three mutations in the acid $\alpha$-glucosidase gene are common in the Dutch patient population: IVS1(-13T $\rightarrow$ G), 525delT and delexon18. 63\% of Dutch GSD II patients carry one or two of these mutations, and the genotype-phenotype correlation is known. To determine the frequency of GSD II, we have screened an unselected sample of neonates for the occurrence of these three mutations. Based on the calculated carrier frequencies, the predicted frequency of the disease is $\mathbf{1}$ in $\mathbf{4 0 0 0 0}$ divided by 1 in 138000 for infantile GSD II and 1 in 57000 for adult GSD II. This is about two to four times higher than previously suggested, which is a reason to become more familiar with the presentation of GSD II in its different clinical forms and to adjust the risk assessment for genetic counselling.
\end{abstract}

Keywords: glycogenosis; Pompe; carrier frequency; genotype frequency

\section{Introduction}

Glycogen storage disease type II (GSD II), acid maltase deficiency or Pompe disease, is an autosomal recessive disease caused by deficiency of the lysosomal enzyme acid $\alpha$-glucosidase. ${ }^{1}$ There are three major phenotypes (infantile, juvenile and adult). The infantile form is characterised by generalised hypotonia and cardiomyopathy. Death occurs within the first two years of life due to cardiorespiratory failure. Late-onset GSD II is

Correspondence: MGEM Ausems, Department of Medical Genetics, University Medical Center Utrecht, PO Box 85090, 3508 AB Utrecht, The Netherlands. Tel: 0302504000; Fax: 030 2503801; E-mail: MG.E.M.Ausems@dmg.azu.nl

Received 22 February 1999; revised 27 April 1999; accepted 11 May 1999 clinically very heterogeneous, and presents at juvenile age to late adulthood as a slowly progressive proximal myopathy. ${ }^{2}$

The prospect of enzyme therapy for GSD II highlights the immediate need for accurate figures on the frequency of the disease. ${ }^{3,4}$ The figure of 1 in 100000 normally quoted is not based on solid data. ${ }^{1,5}$ Given present knowledge of the molecular genetics of GSD II, ${ }^{1,2,6}$ and the genotype-phenotype correlation, ${ }^{7,8}$ we now have the tools to update the meagre and aging data on the frequency of the disease. In order to determine the frequency of GSD II we screened a random sample of newborns for three frequent mutations in the acid $\alpha$-glucosidase gene. These mutations are IVS1 $(-13 \mathrm{~T} \rightarrow \mathrm{G})$, leading to late-onset GSD II, ${ }^{7,9,10}$ and two completely deleterious mutations 525delT and 
delexon18. ${ }^{11-14}$ In total these mutations comprise $63 \%$ of the disease-related alleles in the Dutch patient population. ${ }^{8}$ The screening was performed on DNA extracted from over 3000 Guthrie cards from Dutch neonates.

\section{Materials and Methods}

\section{Sample Collection}

Anonymous Guthrie cards were collected from the central screening laboratory in the Netherlands. The cards were chosen at random from all provinces in proportion to the number of live births in each province.

\section{Mutation Analysis}

The extraction of DNA from the blood spots on the Guthrie cards was according to the method of Walsh et al ${ }^{15}$ with slight modifications. The PCR amplification was performed in a final volume of $25 \mu \mathrm{l}$ containing $10 \mathrm{pmol}$ of each of the appropriate primers, $250 \mu \mathrm{M}$ of each dNTP, $1 \mathrm{~mm} \mathrm{MgCl} 2,10 \%$ DMSO, 1 unit of Taq polymerase (Gibco-BRL, Rockville, Maryland, USA) in $1 \times$ PCR buffer (Gibco-BRL, Rockville, Maryland, USA). The PCR was accomplished in 40 cycles $\left(94^{\circ} \mathrm{C}, 30 \mathrm{~s}\right.$; $59^{\circ} \mathrm{C}, 1 \mathrm{~min} ; 72^{\circ} \mathrm{C}, 30 \mathrm{~s}$ ) preceded by $2 \mathrm{~min}$ at $94^{\circ} \mathrm{C}$ and followed by $10 \mathrm{~min}$ at $72^{\circ} \mathrm{C}$. The primers used for the detection of the IVS1 $(-13 \mathrm{~T} \rightarrow \mathrm{G})$ mutation were: forward 5' TGCTGCAGTGCCAGCCGCGGTTGATGTCT and reverse 5' AGTGCAGCGGTTGCAAGGACACGGAGG; of the 525delT mutation forward 5' GAACCTGAGCTCCTCTGAAATGGGCTAC and reverse 5' CCCACCCTTGTGAGGGTGC; and of the delexon18 mutation forward 5' TGGTTCCTGAGGACACAGCATG and reverse 5' AGTGGCAGGTAGCCATCGGTG. The IVS1($13 \mathrm{~T} \rightarrow \mathrm{G}$ ) and 525delT mutation were detected by MboII and DdeI digestion of the PCR product, respectively, and electrophoresis on a $3 \%$ metaphor-agarose gel. The del exon 18 mutation was detected by fragment size analysis on a $1.5 \%$ agarose gel.

\section{Statistics}

The carrier frequencies of the mild mutation (IVS1 $(-13 \mathrm{~T} \rightarrow \mathrm{G})$ ) and of the two severe mutations (525delT and delexon18) we screened for were directly calculated from the observed number of carriers and the total number of tested Guthrie cards. The overall carrier frequency of severe mutations was calculated by extrapolation using the allele frequencies of the 525delT and delexon18 mutation in 67 Dutch patients with GSD II as determined in our previous study. ${ }^{8}$ Genotype frequencies were calculated assuming Hardy-Weinberg equilibrium.

A support interval (SI) was constructed for the extrapolated carrier frequency of severe mutations $\left(\mathrm{q}_{\mathrm{se}}\right)$, taking into account both the sampling error in the estimated frequency of the two severe mutations tested (525delT and delexon 18) $\left(\mathrm{q}_{\mathrm{st}}\right)$ and the sampling error in the estimated contribution $\left(\mathrm{q}_{\mathrm{st}} /\right.$ $\mathrm{q}_{\mathrm{se}}$ ) of these two mutations to the entire group of all severe mutations found in patients with the infantile form of GSD II. This support interval included all values of $\mathrm{q}_{\mathrm{se}}$ for which -2 times the natural logarithm of the likelihood fell within 3.84 units of the maximum likelihood. It corresponds approximately to a $95 \%$ confidence interval (CI).

\section{Results}

We screened 3043 Guthrie cards for all three mutations (IVS1 $(-13 \mathrm{~T} \rightarrow \mathrm{G}), 525 \mathrm{delT}$ and delexon18). Analyses of these cards revealed a total number of 31 mutations. Thus the calculated carrier frequency of the three mutations was $1 / 100$ (95\% CI: $1 / 69-1 / 144)$. PCR amplification was not always successful for the different gene fragments. In practice, the mild IVS1 $(-13 \mathrm{~T} \rightarrow \mathrm{G})$ mutation was detected in 20 of 3075 samples, leading to a carrier frequency of $1 / 154$ (95\% CI: $1 / 100-1 / 251)$. The severe mutations, 525delT and del exon18, were detected in 7 of 3123 and 4 of 3128 samples, respectively. The calculated carrier frequency of the known severe mutations together was $1 / 284 \quad(95 \%$ CI: $1 / 159-1 / 568)$. Since the $525 \mathrm{delT}$ and del exon18 mutation constitute together $65 \%$ of all severe mutations, ${ }^{8}$ the extrapolated overall carrier frequency of severe mutations is $1 / 187$ (95\% SI: $1 / 105-1 / 368$ ), from which it is assumed that the unknown mutations in patients with

Table 1

A Allele frequency and carrier frequency of mild and severe GSD II mutations

\begin{tabular}{|c|c|c|c|}
\hline Mutation & $\begin{array}{l}\text { Carriers/ } \\
\text { Samples } \\
\text { tested }\end{array}$ & $\begin{array}{l}\text { Allele } \\
\text { frequency }\end{array}$ & $\begin{array}{l}\text { Carrier } \\
\text { frequency }\end{array}$ \\
\hline IVS1 $(-13 \mathrm{~T} \rightarrow \mathrm{G})$ & $20 / 3075$ & $\mathrm{q}_{\mathrm{m}}=0.003252$ & 1 in 154 \\
\hline $\begin{array}{l}525 \text { delT } \\
\text { delexon } 18\end{array}$ & $\begin{array}{l}7 / 3123 \\
4 / 3128\end{array}$ & $\mathrm{q}_{\mathrm{st}}=0.001761$ & 1 in 284 \\
\hline $\begin{array}{l}\text { extrapolated } \\
\text { 'severe' }\end{array}$ & & $\mathrm{q}_{\mathrm{se}}=0.002693$ & 1 in 187 \\
\hline $\begin{array}{l}\text { extrapolated } \\
\text { 'all' }\end{array}$ & & $\mathrm{q}_{\mathrm{e}}=0.005946$ & 1 in 85 \\
\hline
\end{tabular}

B Predicted frequency of GSD II based on the HardyWeinberg equilibrium

$$
95 \% \text { CI }
$$

Infantile GSD II $1 / 138000 \quad 1 / 43 \quad 169-1 / 536485 \quad\left(\mathrm{q}_{\mathrm{se}}{ }^{2}\right)$

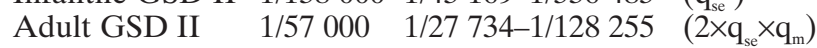

Infantile plus $\quad 1 / 40000 \quad 1 / 17622-1 / 100073 \quad\left(\mathrm{q}_{\mathrm{e}}{ }^{2}-\mathrm{q}_{\mathrm{m}}{ }^{2}\right)^{\mathrm{a}}$ adult GSD II

$\mathrm{q}_{\mathrm{m}}$ : allele frequency of the mild IVS1 $(-13 \mathrm{~T} \rightarrow \mathrm{G})$ mutation $\mathrm{q}_{\mathrm{st}}$ : allele frequency of the two severe mutations tested (525delT and delexon18)

$\mathrm{q}_{\mathrm{se}}$ : extrapolated allele frequency of severe mutations $\mathrm{q}_{\mathrm{e}}$ : extrapolated allele frequency of all GSD II mutations (eg the mild IVS1 $(-13 \mathrm{~T} \rightarrow \mathrm{G})$ mutation and all severe mutations)

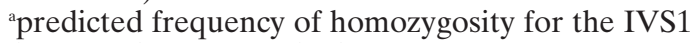
$(-13 \mathrm{~T} \rightarrow \mathrm{G})$ mutation $\left(\mathrm{q}_{\mathrm{m}}{ }^{2}\right)$ is not included because this genotype probably does not give rise to clinical symptoms ${ }^{9,10,16}$. 
Table 2 Risk estimates for having a child affected with infantile or adult GSD II

\begin{tabular}{lccc}
\hline Status of the parent & Infantile GSD II & $\begin{array}{c}\text { Risk of having an affected child } \\
\text { Adult GSD II }\end{array}$ & Total \\
\hline Carrier of IVS1 $(-13 T \rightarrow$ G) & 0 & $1 / 745$ & $1 / 745$ \\
Adult GSD II patient & $1 / 745$ & $1 / 337$ & $1 / 232$ \\
Carrier of 525delT or delexon 18 & $1 / 745$ & $1 / 615$ & $1 / 337$ \\
\hline
\end{tabular}

Risk estimates for infantile and adult GSD II in offspring of a carrier and an unrelated individual depend on the mutation status of the carrier parent.

infantile GSD II are always severe. The overall carrier frequency for all GSD II mutations is $1 / 85$ (95\% SI: $1 / 59-1 / 125)$. Based on these figures, we calculated the frequency of infantile and adult GSD II separately. The frequency of infantile GSD II is $1 / 138000$ (95\% CI: $1 / 43169-1 / 536482$ ), and of late-onset, adult GSD II 1/57.000 (95\% CI: 1/27 734-1/128255). The combined frequency of infantile and adult GSD II is $1 / 40000$ (95\% CI: 1/17622-1/100 073). See also Table 1.

\section{Discussion}

The results from this study predict a combined frequency of infantile and adult GSD II of 1/40000 in the Netherlands. This we consider to be a minimum figure because the unknown mild and severe mutations in adult GSD II patients and the mutations in juvenile GSD II patients are not included in our extrapolations. Therefore the actual frequency of the disease will be higher.

A recent study of randomly selected normal individuals from the New York area of various ethnic origins indicated a carrier frequency of about 1 in 100, based on testing for seven different mutations. ${ }^{17}$ These mutations constitute only $29 \%$ of the chromosomes from 74 GSD II patients, and therefore the extrapolations are considerably less accurate than ours, but coincidentally the estimated frequency of GSD II in the New York study was also 1 in 40000 . Thus, the overall frequency of GSD II is about two to four times higher than previously estimated. This has practical implications for genetic counselling (see Table 2 for risk estimates) and suggests that the disease is underdiagnosed. A reason for this could be that adult GSD II escapes diagnosis when the clinician is not familiar with the various clinical presentations of this rare disease. Alternatively, it is not excluded that individuals with a GSD II genotype may remain asymptomatic. To this end further studies are needed to determine the penetrance of the adult GSD II genotype.

\section{Acknowledgements}

The authors are grateful to the screening laboratories for the use of the Guthrie cards and to B Elvers from the Government for Public Health and Environment (RIVM) for collecting the Guthrie cards of each province. This study was supported by the Dutch Praeventiefonds (grant no. 28-2813).

\section{References}

1 Hirschhorn R: Glycogen storage disease type II: acid $\alpha$-glucosidase (acid maltase) deficiency. In: Scriver CR, Beaudet AL, Sly W, Valle E (eds). The Metabolic and Molecular Bases of Inherited Disease. McGraw-Hill: New York, 1994,pp 2443-2464.

2 Reuser AJJ, Kroos MA, Hermans MMP et al: Glycogenosis type II (acid maltase deficiency). Muscle Nerve 1995; 3 suppl: S61-69.

3 Bijvoet AGA, Kroos MA, Pieper FR et al: Recombinant human acid $\alpha$-glucosidase: high level production in mouse milk, biochemical characteristics, correction of enzyme deficiency in GSD II KO mice. Hum Mol Genet 1998; 7: $1815-1824$.

4 Kikuchi T, Yang HW, Pennybacker $M$ et al: Clinical and metabolic correction of Pompe disease by enzyme therapy in acid maltase-deficient quail. J Clin Invest 1998; 101: 827-833.

5 Chen YT, Burcell A: Glycogen storage diseases. In: Scriver CR, Beaudet AL, Sly W, Valle E (eds). The Metabolic and Molecular Bases of Inherited Disease. McGraw-Hill: New York, 1994, pp 935-965.

6 Raben N, Nichols RC, Boerkoel C, Plotz P: Genetic defects in patients with glycogenosis type II (acid maltase deficiency). Muscle Nerve 1995; 3 suppl: S70-74.

7 Wokke JHJ, Ausems MGEM, Van den Boogaard MJH et al: Genotype-phenotype correlation in adult-onset acid maltase deficiency. Ann Neurol 1995; 38: 450-454.

8 Kroos MA, Van der Kraan M, Van den Boogaard MJ et al: Glycogen storage disease type II: frequency of three common mutant alleles and their associated clinical phenotypes studied in 121 patients. J Med Genet 1995; 32: 836-837.

9 Huie ML, Chen AS, Tsujino S et al: Aberrant splicing in adult onset glycogen storage disease type II (AMD): molecular identification of an IVS1 $(-13 \mathrm{~T} \rightarrow \mathrm{G})$ mutation in a majority of patients and a novel IVS10 $(+1 \mathrm{GT} \rightarrow \mathrm{CT})$ mutation. Hum Mol Genet 1994; 3: 2231-2236. 
10 Boerkoel CF, Exelbert R, Nicastri C et al: Leaky splicing mutation in the acid maltase gene is associated with delayed onset of glycogenosis type II. Am J Hum Genet 1995; 56: 887-897.

11 Hermans MMP, De Graaff E, Kroos MA et al: The effect of a single base pair deletion $(\Delta \mathrm{T} 525)$ and a C1634T missense mutation (Pro545Leu) on the expression of lysosomal $\alpha$-glucosidase in patients with glycogen storage disease type II. Hum Mol Genet 1994; 3: 2213-2218.

12 Huie ML, Chen AS, Sklower Brooks S, Grix A, Hirschhorn R: A de novo $13 \mathrm{nt}$ deletion, a newly identified C647W missense mutation and a deletion of exon 18 in infantile onset glycogen storage disease type II (GSD II). Hum Mol Genet 1994; 3: 1081-1087.

13 Van der Kraan M, Kroos MA, Joosse M et al: Deletion of exon 18 is a frequent mutation in glycogen storage disease type II. Biochem Biophys Res Commun 1994; 203: 1535-1541.
14 Ausems MGEM, Kroos MA, Van der Kraan M et al: Homozygous deletion of exon 18 leads to degradation of the lysosomal $\alpha$-glucosidase precursor and to the infantile form of glycogen storage disease type II. Clin Genet 1996; 49: $325-328$

15 Walsh PS, Metzger DA, Higuchi R: Chelex®100 as a medium for simple extraction of DNA for PCR-based typing from forensic material. BioTechniques 1991; 10: 506-513.

16 Raben N, Nichols RC, Martiniuk F, Plotz PH: A model of mRNA splicing in adult lysosomal storage disease (glycogenosis type II). Hum Mol Genet 1996; 7: 995-1000.

17 Martiniuk F, Chen A, Mack A et al: Carrier frequency for glycogen storage disease type II in New York and estimates of affected individuals born with the disease. $\mathrm{Am}$ J Med Genet 1998; 79: 69-72. 